\title{
BLACK MADNESS
}




\section{:: MAD BLACKNESS}

THERÍ ALYCE PICKENS Duke University Press Durham and London 2019 
(C) 2019 Duke University Press

All rights reserved

Printed in the United States of America on acid-free paper $\infty$

Designed by Courtney Leigh Baker

Typeset in Garamond Premier Pro and Knockout by Copperline Books

Library of Congress Cataloging-in-Publication Data

Names: Pickens, Theri A., author.

Title: Black madness : : mad Blackness / Theri Alyce Pickens.

Description: Durham : Duke University Press, 2019. | Includes

bibliographical references and index.

Identifiers: LCCN 2018040998 (print) | LCCN 2018056886 (ebook)

ISBN 978 I 478005506 (ebook)

IS BN 9781478003748 (hardcover : alk. paper)

ISBN 9781478004042 (pbk. : alk. paper)

Subjects: LCSH: Minority people with disabilities-United States. | African Americans with disabilities_United States. | People with disabilities-United States. | Discrimination against people with disabilities-United States. | American fiction-African American authors-History and criticism. | Science fiction, AmericanHistory and criticism. | Race in literature. | People with disabilities in literature. | African Americans-Study and teaching. | Disability studies-United States.

Classification: LCC HVi569.3.M55 (ebook) | LCC HVi569.3.M55 P53 2019 (print) | DDC 362.4089/96073-dc23

LC record available at https://lccn.loc.gov/2018040998

Duke University Press gratefully acknowledges the support of the Roger J. Schmutz Fund at Bates College, which provided funds toward the publication of this book.

Cover art: Lorna Simpson, Enumerated, 2016. Ink and screenprint on claybord. $36 \times 24 \times 3 / 4$ in. (C) Lorna Simpson. Courtesy the artist and Hauser $\&$ Wirth. 
For the MAD BLACK and BLACK MAD everywhere 
This page intentionally left blank 